\title{
Sunflower 1000-Seed Weight as Affected by Year and Genotype
}

\author{
Velimir Radić • Jelena Mrđa • Milan Jocković • Petar Čanak • \\ Aleksandra Dimitrijević • Siniša Jocić
}

\author{
received: 9 January 2013, accepted: 29 April 2013 \\ published online: 28 May 2013 \\ (c) 2013 IFVC \\ doi: $10.5937 /$ ratpov50-3214
}

\begin{abstract}
Summary: For a successful seed production, it is necessary to know the size, i.e. 1000-seed weight, since it affects the sowing rate, plant density over the vegetative period as well as the seed yield per unit area. The study was conducted in field conditions, on plots where seed production of sunflower hybrids parental components was organized. Seed production was based at three different localities. Observation was conducted during the course of three years. The study was performed on 18 different genotypes. Considering the total number of the observed genotypes, 10 genotypes represented lines based on CMS, while the remaining 8 genotypes represented restorer lines. The study showed that 1000-seed weight was higher with CMS based lines than with restorer lines, which was expected considering the branching of the restorer lines. Sunflower 1000-seed weight depended on the year of observation and the observed genotype. Year had a significant effect on 1000 -seed weight.
\end{abstract}

Key words: 1000 seed weight, CMS, parental lines, restorer lines, sunflower seed, seed size

\section{Introduction}

Sunflower is the plant species primarily grown in Serbia for the production of edible oil, and it is used as a high protein and honey-bearing plant to a lesser extent. Because of the relatively large area of sunflower growing and diverse growing conditions, it is necessary to produce high quality seed able to germinate immediately after harvest (Vujaković et al. 2012).

Seed is characterized by nearly 100 distinctive features. Only 20 of them are significant for the market, while 10 to 15 of features are being tested. One of the tested seed features is 1000seed weight (Mirić et al. 2006). Along with the development of knowledge and technical precision sowing of most crop plants, weight of 1000 seeds is gaining importance as a factor in achieving precise planting, which later indirectly (through planting density) affects the yield per unit area. It is believed that it is very important to sow hybrid seed with a high 1000 -seed weight

V. Radić • J. Mrđa • M. Jocković • P. Čanak • A. Dimitrijević • S. Jocić Institute of Field and Vegetable Crops, M. Gorkog 30, 21000 Novi Sad, Serbia

e-mail: velimir.radic@nsseme.com because such seed has more spare nutrients, more developed embryo, and plants that develop from it grow faster, which is often very important in adverse climatic and edaphic conditions (Hladni 2007). Hereditary factors crucially influence this feature, although its size can be improved by adequate agricultural measures and seed processing by separation to fractions (Mirić \& Brkić 2002).

1000-seed weight is one of the most important quality factors. This factor varies between different plant species, varieties and hybrids within one species and conditions of growing (Radić 2008). 1000-seed weight represents variety feature and is a reflection of grain sturdiness and filling. Joksimović et al. (2004) claim that 1000 -seed weight is a variable trait, and as such it is under influence of genetic and environmental factors. Variability in size of this trait is characteristic both for different genotypes at one locality and for one genotype at different

\section{Acknowledgements:}

This research is part of the project TR31025 titled "Development of new varieties and production technology improvement of oil crops for different purposes", financed by the Ministry of Education, Science and Technological Development of the Republic of Serbia. 
localities (Marinković et al. 1994). By studying the effect of harvest date with three sunflower genotypes at two localities, Miklič et al. (2006) reached similar conclusions on changeability of 1000-seed weight.

Feoli et al. (1993) and Villalobos et al. (1994) claim that 1000 -seed weight mainly depends on the year, choice of hybrid and plant density. In their research on soybean, Đukić et al. $(2010,2011)$ noted the significant effect of the year as a factor on yield and 1000-seed weight. Same authors concluded that increase of favourable conditions during the vegetation increases both seed yield per unit area and 1000-seed weight.

By observing all quantitative traits which are in significant correlation with sunflower seed yield, Marinkovic et al. (2003) argue that the direction of selection for yield one of the most unsafe directions, because the weight of 1000 seeds in addition to plant density is influenced by environmental factors. Vratarić \& Sudarić (2004) concluded that variability of 1000 -seed weight is characteristic for both different genotypes at one locality and the same genotype at different localities. The same authors asserted that beside variability of seed weight per locality and per genotype, this variability exists in some genotypes between different circles of sunflower head as well.

The aim of this study was to determine whether year of production and choice of genotype affect 1000-seed weight of the observed sunflower parental lines.

\section{Materials and Methods}

The experiment was carried out in field conditions during three years on plots where seed production of sunflower parental lines was established. The established seed production took place at one locality. Eighteen genotypes were examined, ten of which represented lines based on CMS and eight of them were restorer lines. All the examined genotypes represent parental components of the best-selling sunflower hybrids developed at Institute of Field and Vegetable Crops, Novi Sad, Serbia. Upon seed drying, samples were purified and cleaned. Seed for determining the remaining observed parameter was picked from the given samples. Examination of 1000-seed weight was repeated 4 times, and each time 100 seeds were used. The obtained value was applied to 1000 seed weight and was specified in grams. Data were analysed using two-way ANOVA for a completely randomized design.

\section{Results}

\section{0-seed weight in sterile lines}

Table 1 shows the analysis of variance of the examined parameter. On the basis of the obtained results it can be concluded that statistically there was highly significant effect of the year, line as a genotype, and interaction between year and genotype on 1000-seed weight.

If we compare the obtained results on average we can see that the highly significant difference between all three years of observation was found. The highest average value of weight of 1000 seeds $(67.35 \mathrm{~g})$ was found in 2003 while in 2002 it was established by the lowest average value of weight of 1000 seeds $(62.00 \mathrm{~g})$.

The lowest value for seed weight in 2002 (Table 2) was determined for L-9 line (39.4 g), while L-2 line had the highest value of 1000 -seed weight

Table 1. Analysis of variance for sterile lines

Tabela 1. Analiza varijanse za sterilne linije

\begin{tabular}{lrrrrc}
\hline $\begin{array}{l}\text { Source of variation } \\
\text { Izvor varijacije }\end{array}$ & DF & SS & MS & F test & P \\
\hline $\begin{array}{l}\text { Year (Y) } \\
\text { Godina }\end{array}$ & 2 & 451.441 & 225.720 & 517.58 & $<0.001^{* *}$ \\
$\begin{array}{l}\text { Error Y } \\
\text { Pogreška }\end{array}$ & 4 & 1.744 & 0.436 & 0.92 & \\
Line (L) & 9 & 6752.472 & 750.275 & 1586.78 & $<0.001^{* *}$ \\
Linija & 18 & 2249.706 & 124.984 & 264.33 & $<0.001^{* *}$ \\
Yx L & 54 & 25.533 & 0.473 & & \\
Error L & 99 & 9480.978 & & & \\
Pogreška & 89 &
\end{tabular}

"- significant at 0.01 level of probability / značajno na nivou 0,01 
(75.0 g). In 2003 determined lines weight span was from $55.6 \mathrm{~g}$ for L-3 line to $84.3 \mathrm{~g}$ for L-2 line. In the last year of observation, average weight was with the span from $53.2 \mathrm{~g}$ to $78.0 \mathrm{~g}$. The smallest seed, as in the last year, was determined for L-3 line, while L-2 line, just like in the last two years of observation, was determined to have the highest 1000-seed weight.

L-2 line is characterized by the biggest seed of all observed sterile lines $(79.10 \mathrm{~g})$ on average. Highly significant difference was determined with respect to values of all other lines. On the basis of seed size, the next line is $\mathrm{L}-1(74.37 \mathrm{~g})$. In comparison with the rest of the observed lines we determined highly significant differences. The same situation was determined during the comparison of other observed lines, i.e. highly significant difference was determined between all observed sterile lines. The smallest seed among the observed lines was determined for L-9 (53.53 g) and L-8 (56.70 g) lines.

During observation of influence of the year $(\mathrm{Y} \times \mathrm{L})$ in same line on 1000-seed weight we determined highly significant differences. Only values of L-6, determined in 2002 and 2003, did not have significant difference.

Table 2. 1000-seed weight of sterile lines (g)

Tabela 2. Masa 1000 semena sterilnih linija

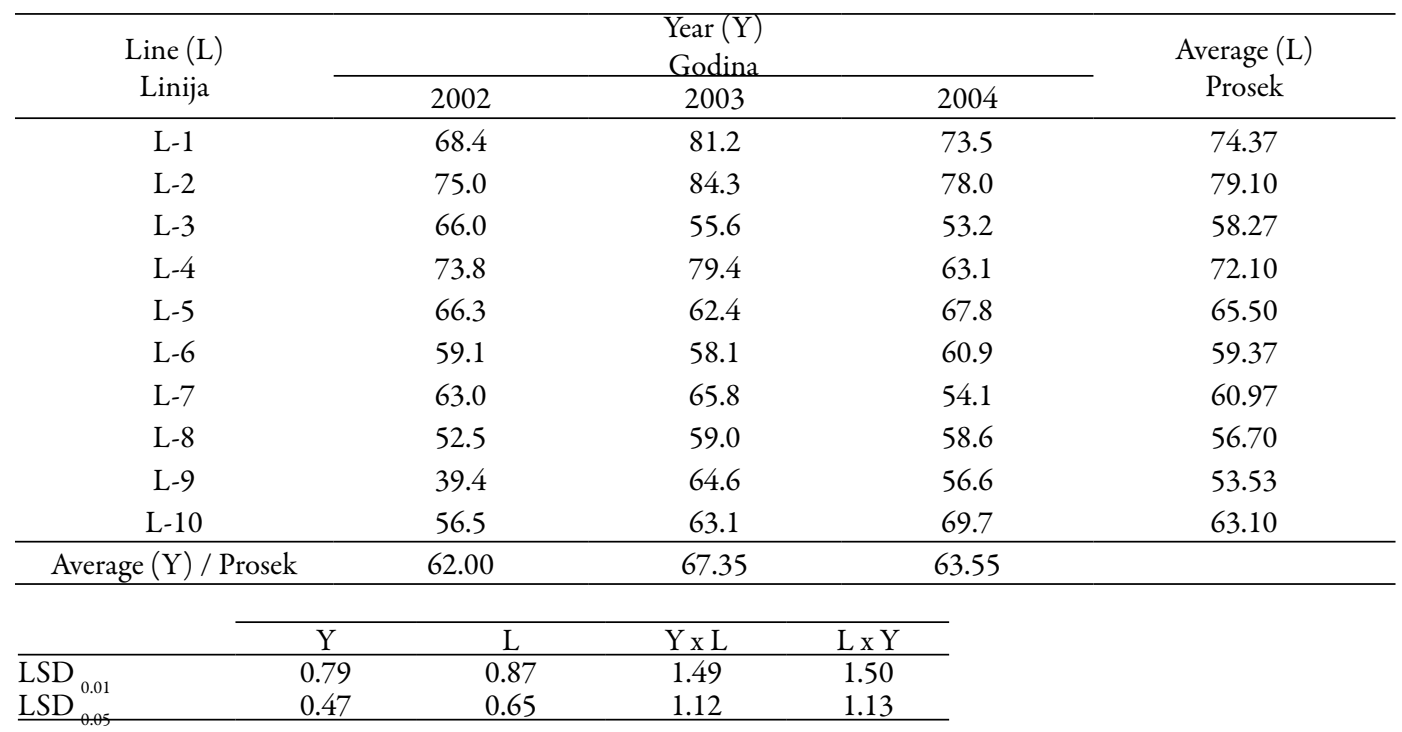

Table 3. Analysis of variance for restorer lines

Tabela 3. Analiza varijanse za linije restorera

\begin{tabular}{|c|c|c|c|c|c|}
\hline $\begin{array}{l}\text { Source of variation } \\
\text { Izvor varijacije }\end{array}$ & $\mathrm{DF}$ & SS & MS & F test & $\mathrm{P}$ \\
\hline $\begin{array}{l}\text { Year }(Y) \\
\text { Godina }\end{array}$ & 2 & 49.470 & 24.735 & 28.98 & $<0.004^{* *}$ \\
\hline $\begin{array}{l}\text { Error Y } \\
\text { Pogreška }\end{array}$ & 4 & 3.414 & 0.854 & 1.49 & \\
\hline $\begin{array}{l}\text { Restorer (R) } \\
\text { Restorer }\end{array}$ & 7 & 6006.399 & 858.057 & 1500.40 & $<0.001^{* *}$ \\
\hline$Y \times R$ & 14 & 540.841 & 38.631 & 67.55 & $<0.001^{* *}$ \\
\hline $\begin{array}{l}\text { Error R } \\
\text { Pogreška } \\
\end{array}$ & 42 & 24.019 & 0.572 & & \\
\hline Total & 71 & 6625.743 & & & \\
\hline
\end{tabular}

"* significant at 0.01 level of probability / značajno na nivou 0.01 
Table 4. 1000-seed weight of restorer lines (g)

Tabela 4. Masa 1000 semena linija restorera

\begin{tabular}{ccccc}
\hline \multirow{2}{*}{$\begin{array}{c}\text { Restorer }(\mathrm{R}) \\
\text { Restorer }\end{array}$} & \multicolumn{3}{c}{$\begin{array}{c}\text { Year }(\mathrm{Y}) \\
\text { Godina }\end{array}$} & $\begin{array}{c}\text { Average }(\mathrm{R}) \\
\text { Prosek }\end{array}$ \\
\cline { 2 - 4 } & 2002 & 2003 & 2004 & 50.70 \\
R-1 & 51.1 & 44.5 & 56.5 & 28.03 \\
R-2 & 23.9 & 29.1 & 31.1 & 32.30 \\
R-3 & 30.9 & 36.6 & 29.4 & 51.33 \\
R-4 & 51.8 & 54.2 & 48.0 & 49.70 \\
R-5 & 45.4 & 53.3 & 50.4 & 35.57 \\
R-6 & 34.8 & 36.1 & 35.8 & 39.23 \\
R-7 & 39.1 & 41.8 & 36.8 & 52.43 \\
R-8 & 53.7 & 51.2 & 52.4 & \\
\hline Average (Y) / Prosek & 41.34 & 43.35 & 42.55 & \\
\hline
\end{tabular}

\begin{tabular}{lcccc} 
& $\mathrm{Y}$ & $\mathrm{R}$ & $\mathrm{Y} \times \mathrm{R}$ & $\mathrm{R} \times \mathrm{Y}$ \\
\hline LSD $_{0.01}$ & 1.23 & 0.96 & 1.72 & 1.67 \\
LSD $^{0.74}$ & 0.74 & 0.72 & 1.28 & 1.25 \\
\hline
\end{tabular}

Like in previously observed parameters, there are highly significant differences between lines in same years of examination ( $\mathrm{L} \times \mathrm{Y})$. Good examples for this are L-7 and L-9 lines. If we compare their values, determined in 2003, we get a significant difference. In all other cases, there is a highly significant difference between the observed lines.

\section{0-seed weight in restorer lines}

Based on variance values analysis, it can be concluded that statistically there was a highly significant effect of the line as a genotype and interaction between the year and the genotype on 1000-seed weight (Table 3 ).

In 2002, restorer lines were characterized by average weight of $41.34 \mathrm{~g}$ (Table 4). In 2003, average 1000 -seed weight was $43.35 \mathrm{~g}$, while in last year of observation average 1000-seed weight was $42.55 \mathrm{~g}$. Highly significant difference was determined during comparison of average 1000-seed weight obtained in 2002 and 2003. Unlike this comparison, existence of significant difference was determined during observation of average values obtained between 2002 and 2004 and between 2003 and 2004 .

In 2002, the lowest value of 1000-seed weight was determined for R-2 restorer line $(23.9 \mathrm{~g})$, while R-8 restorer had the largest seed $(53.7 \mathrm{~g})$. In 2003, value of 1000-seed weight ranged from $29.1 \mathrm{~g}$ for R-2 to $54.2 \mathrm{~g}$ for R-4 restorer line. In 2004 , the value of the determined weight moved from $29.4 \mathrm{~g}$ to $56.5 \mathrm{~g}$. Restorer line R-3, had the smallest seed, while R-1 restorer line had the largest seed.

When restorers are taken individually, the smallest average 1000 -seed weight for three years of observation was determined for R-2 (28.03 g) restorer. Second place, according to average 1000seed weight, belongs to R-3 restorer $(32.30 \mathrm{~g})$. The highest average value for 1000 -seed weight was determined for R-8 restorer line (52.43 g), followed by R- 4 restorer with the highest value of average 1000 -seed weight $(51.33 \mathrm{~g})$. Significant difference was determined during the comparison of the obtained values of the last two mentioned restorers. The same situation was identified during the comparison of the obtained values of $\mathrm{R}-1$ and R-5 restorers. No significant difference was found between R-1 and R-4 restorers. However, highly significant difference was found during the comparison of the obtained values of the remaining observed restorers.

Comparing values of 1000-seed weight of the same restorer $(Y \times R)$, in different years, we determined highly significant differences. Statistically significant differences were not found for R-6 and R-8 restorers. By comparison of the obtained values between years of 2002 and 2004 or between 2003 and 2004, there are no statistically significant differences were found for R-6 restorer. By comparison of the realized values in 2002 and 2003, statistically significant differences were found. For restorer R-8 highly significant differences were found between values 
of 2002 and 2003. By comparison between realized values in 2002 and 2004, statistically significant differences were found. No significant differences were found by comparison of realized values in 2003 and 2004.

It was determined that between lines in the same year $(\mathrm{Lx} Y)$ in 2002 there were no significant differences between R-1 and R-4 restorers, whereas there was a highly significant difference in all other comparisons. There was no significant difference in 2003 between restorers R- 4 and R-5 or between R-3 and R-6. Highly significant difference was found in all other comparisons. Unlike previous year, differences were found between values of R-6 and R-7 restorers in 2004 . Significant difference was found between R-2 and $\mathrm{R}-3$ restorers, while highly significant difference was found in all other observations.

\section{Discussion}

Results showed that among observed sterile lines, line L-2 had the biggest 1000-seed weight in a three-year period of examination $(79.1 \mathrm{~g})$. $\mathrm{R}-4$ restorer had the best results regarding 1000 seed weight $(51.3 \mathrm{~g})$. Unlike mentioned lines, L-9 $(53.5 \mathrm{~g})$ sterile line and R-2 $(28.0 \mathrm{~g})$ restorer had the smallest 1000 -seed weight. Found differences were expected, since 1000-seed weight was usually higher with sterile lines, with respect to restorer lines. Mainly, the difference is that the restorer lines are characterized by side branches. With most restorers, presence of side branches directly affects the reduction of sunflower head size, which also makes the seed smaller.

1000-sunflower seed weight depended on the year and the genotype, which was supported by analysis of variance. Years, as factor of observation, had a significant effect on 1000-seed weight. Statistically highly significant differences were found between results obtained in the years of observation. Statistically highly significant difference was also found with observed sterile lines and with restorer lines. The highest 1000seed weight of sterile lines was found in 2003, while the smallest value was found in 2002 . The same situation was determined for the observed restorer lines. Restorer lines had the largest seed in 2003, while the smallest seed was characteristic for the year 2002. Since the year 2003 was extremely dry, achieved results of the 1000-seed weight lead to the conclusion that high temperatures, during the flowering period, affected pollen to die faster, which further affected the reduction of pollination and fertility, while on the other hand it ensured newly formed seed less competition for nutrients needed for development, filling and grain maturity, as well as more space on sunflower head. Škorić (1989) reached the same conclusion in his research, saying that there was a highly negative correlation between seed size and the number of seed per plant. As a reason for this, Škorić says that if a genotype forms most of the seeds, each formed seed has fewer nutrients on disposal.

If genotype is regarded as a factor, for sterile lines, the least variability in 1000-seed weight was found in L-6 line (on the basis of which it can be concluded that effect of the year as factor on weight of this line was small), while the largest oscillation in achieved 1000-seed weight was found in L-1 and L-9 lines. The smallest 1000seed weight for both of the above mentioned lines was accomplished in 2002, unlike for L-6 line (for which the smallest 1000-seed weight was in 2003). With restorer lines, the least oscillation in 1000-seed weight was determined for R-6 and R-8 restorers. Restorers reacted differently to the effect of the year. The year 2003 was the most favourable year for R-6 restorer (the highest 1000seed weight value), while it was most unfavourable for R-8 restorer if we observe 1000-seed weight. The most favourable year for this restorer was 2002, while this year was the most unfavourable for R-6. The largest oscillation between obtained values, i.e. significant influence of the year on restorer was determined for R-1, R-2 and R-5. Jocić (2002) concluded highly significant effect of genotype on 1000-seed weight.

Cupina \& Sakač (1989) and Vratarić \& Sudarić (2004) agree with the conclusion that beside external factors and the choice of genotypes, regarding 1000-seed weight, position of the seed in sunflower head also has the significant effect. Miklič (2001) says that it is logical to expect somewhat larger seed in years when high temperatures influenced the reduction of fertility. The same author also states that a larger amount of precipitation and lower temperatures cause longer grain filling period and the increase of sunflower seed size as well. Dornbos \& McDonald (1986) also agree with this conclusion since they found high influence of climate factors on grain forming by examining 1000-seed weight of soybean. They further conclude that the highest influence of these factors was determined after the flowering was finished. Miklič et al. (2006) claim that the time of harvest affected 1000-seed weight in such a manner that seed weight linearly grew up to the last date of harvest. On the basis of their research, Čanak et al. (2011) concluded that values of 1000 -seed weight grew up to 28 
days after flowering time was finished, after which there was no significant growth of the observed parameter.

Dušanić (1998) and Marinković et al. (1994) concluded that 1000-seed weight primarily depended on the year of production, chosen hybrid for production and plant density per unit area. Dušanić (1998) further claims that the increase of density (number of plants) per unit area lead to significant reduction of 1000-seed weight.

\section{Conclusions}

1000-seed weight depended on both the year of observation and the observed genotype. Year as a factor of observation had significant effect on 1000-seed weight. Beside years, we have concluded in this research that genotype also has a significant influence on 1000-seed weight.

Sterile lines had larger seed with respect to restorer lines seed. This can be primarily explained by the fact that all the observed restorer lines have side branches.

The largest seed was characteristic for L-2 line, while the lowest value of 1000 -seed weight for all the observed sterile lines was characteristic for L-9 line. The largest seed was determined for R-8, while R-2 restorer had the smallest seed.

By observing the obtained values of 1000-seed weight, the most favourable year for production was 2003 , while the most unfavourable was 2002. Such conclusion can be stated for both the observed sterile lines and restorer lines.

\section{References}

Čanak, P., Radić, V., Mrđa, J., Jocković, M., Ćirić, M., \& Miklič, V. (2011). Uticaj momenta desikacije na masu 1000 semena suncokreta. Ratar. Povrt. 48, 391-396.

Ćupina, T., \& Sakač, Z. (1989). Fiziološki aspekti formiranja prinosa suncokreta. Poljoprivredni fakultet, Institut za ratarstvo i povrtarstvo, Novi Sad.

Dornbos, D.L., \& McDonald, Jr M.B. (1986). Mass and composition of developing soybean seeds at five reproductive growth stages. Crop Sci. 26, 624-630.

Dušanić, N. (1998). Uticaj gustine useva na dinamiku rastenja i prinos hibrida suncokreta, kao i neke mikroklimatske cinioce. Doctoral dissertation. University of Novi Sad, Faculty of Agriculture.

Đukić, V., Đorđević, V., Popović, V., Balešević-Tubić, S., Petrović, K., Jakšić, S., \& Dozet, G. (2010). Efekat azota i nitragina na prinos i sadržaj proteina. Ratar. Povrt. 47, 187-192.
Đukić, V., Balešević-Tubić, S., Đorđević, V., Tatić, M., Dozet, G., Jaćimović, G., \& Petrović, K. (2011). Prinos i semenski kvaliteti soje u zavisnosti od uslova godine. Ratar Povrt. 48, 137-142.

Feoli, C.E., Schneiter, A.A., \& Johnson, B.L. (1993). Agronomic performance of dwarf, semidwarf, and conventional height sunflower hybrids grown at five plant populations under rainfed conditions. Helia 16, 19-30.

Hladni, N. (2007). Kombinacione sposobnosti i način nasledivanja prinosa $i$ komponenti prinosa suncokreta (Helianthus annuus L.). Doctoral dissertation. University of Novi Sad, Faculty of Agriculture.

Jocić, S. (2002). Nasledivanje komponenti prinosa kod suncokreta (Helianthus annuus L.). Doctoral dissertation. University of Novi Sad, Faculty of Agriculture.

Joksimović, J., Atlagić, J., Jovanović, D., Marinković, R., Dušanić, N., \& Miklič, V. (2004). Path coefficient analysis of some head and seed characteristics in sunflower. Proc 16th International Sunflower Conference, Fargo, North Dakota, USA, 525-530.

Marinković, R., Škorić, D., Nenadić, N., Jovanović, D., Miklič, V., Joksimović, J., Stanojević, D., \& Nedeljković, S. (1994). Uticaj položaja semena u glavi na prinos i neke komponente prinosa semena kod suncokreta (Helianthus annuus L.). Zbornik radova Instituta za ratarstvo i povrtarstvo 22, 379-389.

Marinković, R., Dozet, B., \& Vasić, D. (2003). Oplemenjivanje suncokreta. Školska knjiga, Novi Sad.

Miklič, V. (2001). Uticaj momenta desikacije na semenski kvalitet i prinos suncokreta. Doctoral dissertation. University of Novi Sad, Faculty of Agriculture.

Miklič, V., Dušanić, N., Joksimović, J., \& Crnobarac, J. (2006). Uticaj vremena berbe na masu 1000 semena različitih genotipova suncokreta. Zbornik radova, 47. Savetovanje industrije ulja, Herceg Novi, 55-61.

Mirić, M., \& Brkić, M. (2002). Dorada semena. Društvo selekcionera i semenara Republike Srbije, Beograd.

Mirić, M., Selaković, D., Jovin, P., \& Hojka, Z. (2006). Masa 1000 semena u teoriji i praksi. Zbornik abstrakata, IV Simpozijum selekcije i semenarstva, Zlatibor, p. 172.

Radić, V. (2008). Proizvodne i morfološke osobine komercijalnih novosadskih linija suncokreta (Helianthus annuus L.). Doctoral dissertation. University of Novi Sad, Faculty of Agriculture.

Škorić, D. (1989). Dostignuća i dalje pravci u oplemenjivanju suncokreta (pp. 285-392). In: D Škorić (ed): Suncokret. Nolit, Beograd. 
Vujaković, M., Radić, V., Miklič, V., Jovičić, D., Balešević-Tubić, S., Mrđa, J., \& Škorić, D. (2012). Seed dormancy of hybrids and parent lines of sunflower (Helianthus annuus L.). Helia 35, 111-118.

Vratarić, M., \& Sudarić, A. (2004). Oplemenjivanje i genetika suncokreta (pp. 88-89). In: M Vratarić (ed): Suncokret Helianthus annuus L. Poljoprivredni institut, Osijek.

Villalobos, F.J., Sadras, V.O., Soriano, A., \& Fereres, E. (1994). Planting density effect on dry matter partitioning and productivity of sunflower hybrids. Field Crop. Res. 36: 1-11.

\title{
Masa 1000 semena suncokreta u zavisnosti od godine i genotipa
}

\author{
Velimir Radić • Jelena Mrđa • Milan Jocković • Petar Čanak • \\ Aleksandra Dimitrijević • Siniša Jocić
}

Izvod: Za uspešnu semensku proizvodnju neophodno je poznavati krupnoću, tj. masu 1000 semena jer ona utiče na setvenu normu, optimalan sklop biljka u toku vegetacije, a samim tim i na prinos semena po jedinici površine. Ispitivanje je vršeno u poljskim uslovima na parcelama gde je organizovana semenska proizvodnja roditeljskih komponenti hibrida suncokreta. Semenska proizvodnja organizovana je na tri različita lokaliteta. Posmatranje se odvijalo tokom tri godine. Ispitivanje je obavljeno na 18 različitih genotipova. Od ukupnog broja posmatranih genotipova, 10 genotipova predstavljale su linije na bazi CMS-a, dok su preostalih 8 genotipova predstavljale restorer linije. Ispitivanja su pokazala da je masa 1000 semena veća kod linija na bazi CMS-a u odnosu na restorer linije, što je bilo i za očekivati s obzirom na granatost linija restorera. Masa 1000 semena suncokreta zavisila je od godine posmatranja i posmatranog genotipa. Godine kao faktor posmatranja imale su značajnog uticaja na masu 1000 semena.

Ključne reči: CMS, krupnoća semena, masa 1000 semena, restorer linije, roditeljske linije, seme suncokreta 